\title{
61. EXAMINATION OF SOME DSDP LEG 42A SAMPLES CONTAINING PTEROPODA ${ }^{1}$
}

\author{
L. Pastouret, Centre National pour l'Exploitation des Océans, Brest, France
}

\section{SITE 376 WEST OF CYPRUS}

\section{Sample 1-1, 84-85 cm}

Lithologic Unit I, gray to brown nannofossil marls with interlayered tephra and sapropels, age: Pleistocene.

The coarse fraction $(\phi>63 \mu \mathrm{m})$ is scarce. The dominant planktonic foraminifers are: Turborotalia quinqueloba, Globorotalia inflata, Globigerinoides ruber, Globigerinoides pyramidalis.

Pteropoda are very rare, only three species were found: Limacina inflata (d'Orbigny), Diacria trispinosa (Blainville) forma major (Boas), and Creseis virgula (Rang) forma constricta (Chen and Bé).

The large amount of the coarse fraction frequency is due to the presence of the large Pteropoda (Diacria).

\section{Sample 2-1, 80-82 cm}

Lithologic Unit I.

The coarse fraction is very abundant $(0.2 \mathrm{~g})$ containing mostly planktonic foraminifers, some benthic species were present; fibrous volcanic glass shards were found.

The dominant planktonic foraminifer species are: Orbulina universa, Globorotalia inflata, G. scitula, $G$. oscitans, Turborotalia quinqueloba, Globigerinoides ruber, G. pyramidalis, Globigerina bulloides, G. pachyderma dextral coiling, G. pachyderma eggeri, dextral and sinistral coiling. The pteropod fauna is scarce, only two species were present: Clio pyramidata (L) and Limacina retroversa (Flemming), adult and juvenile specimens.

These assemblages are characteristic in the Mediterranean area of cool water prevailing during cold paleoclimatic periods.

The present biogeographical distribution of Limacina retroversa is restricted to the northeast Atlantic and to areas such as the Norwegian Sea, the North Sea, the English Channel, off Ireland, and occasionally in the Bay of Biscaye (Van der Spoel, 1972; Tesch, 1946). The species is now absent in the Mediterranean Sea (Rampal, 1975), but was very abundant during cold paleoclimatic periods (Würm Stage) and even in the Holocene (subboreal) in both the western and eastern Mediterranean (Blanc-Vernet et al., 1969;

\footnotetext{
${ }^{1}$ Editors Note: This contribution is simply a listing of those samples submitted to this shorebase laboratory which contained pteropods, together with descriptive notes on each.
}

Pastouret, 1970; Herman, 1972). It has an epipelagic vertical range and may move very quickly in response to climatic variations from one region to another.

\section{Sample 2-4, 75-77 cm}

\section{Lithologic Unit I}

In the coarse fraction biogenic material is very abundant comprising mostly planktonic foraminifers, ostracodes, echinoid spines, fish bones, etc. Also present are muddy agglomerate (sieving?), pyrite burrow-filling, and also many detrital grains.

The most frequent planktonic foraminifers are: Globorotalia inflata, G. truncatulinoides (with senestral or dextral coiling), Globigerinoides ruber.

The pteropod fauna contains: Clio pyramidata (L), Limacina inflata (d'Orb.), Limacina trochiformis (d'Orb.).

This type of sediment would have been deposited during a warm temperate period with poor oxygenation at the sea bottom.

\section{Sample 3-1, 115-117 cm}

Lithologic Unit I.

Coarse material $(\phi>63 \mu \mathrm{m})$ is very abundant, mostly composed of planktonic foraminifers; ostracodes and volcanic glass are also present.

The most frequent planktonic foraminifers are: Orbulina universa, Globorotalia inflata, and G. scitula.

The pteropod fauna contains only two species: Clio pyramidata (L) and Cavolinia inflexa (Lesueur).

\section{SITE 377, IONIAN SEA}

\section{Core 4, Section 1}

Lithologic Unit III, nannofossil and silty marlstones with calcareous silt and sandstones; age: Miocene.

The coarse fraction is very abundant containing a mixed microfauna of Miocene and Pleistocene age (downhole contamination?).

Pleistocene planktonic foraminifers found are: Globorotalia inflata, Orbulina universa, Globigerinoides ruber (white and pink specimen), G. pyramidalis, G. quadrilobatus, and Globigerina bulloides.

The pteropod fauna comprises two species of Pleistocene age: Clio pyramidata (L) and Limacina inflata (d'Orb.).

Table 1 gives quantitative information on the samples studied. 
TABLE 1

Quantitative Information, Sites 376 and 377

\begin{tabular}{crcr}
\hline $\begin{array}{c}\text { Sample } \\
\text { (Interval in cm) }\end{array}$ & $\begin{array}{c}\text { Sample } \\
\text { Weight }\end{array}$ & $\begin{array}{c}\text { Coarse Fraction } \\
\text { Weight }\end{array}$ & $\begin{array}{c}\text { \% Coarse } \\
\text { Fraction }\end{array}$ \\
\hline Site 376 & & & \\
1-1, 84-85 & 0.045 & 0.01 & 22.2 \\
$2-1,80-82$ & 6.160 & 0.238 & 3.8 \\
3-1, 75-77 & 12.211 & 0.675 & 5.5 \\
Site 377 & & & \\
$4-1, ?$ & 4.501 & 0.893 & 19.8 \\
\hline
\end{tabular}

\section{REFERENCES}

Blanc-Vernet, L., Chamley, H., and Froget, C., 1969. Analyse paléoclimatique d'une carotte de Méditerranée nordoccidentale. Comparaison entre les résultats de trois études: foraminifères, ptéropodes, fraction sédimentaire issue du continent: Paleogeogr., Paleoclimatol. Paleoecol., v. 6 , p. $215-235$.

Herman, Y., 1972. Quaternary eastern Mediterranean sediments: Micropaleontology and climatic record. In Stanley, D. J. (Ed.), The Mediterranean Sea: a natural sedimentation laboratory, p. 129-147.

Pastouret, L., 1970. Etude sédimentologique et paléoclimatique des carottes prélevées en Méditerranée orientale: Tethys, v. 2, p. 227-266.

Rampal, J., 1975. Les thécosomes. Systématique et évolution. Ecologie et biogéographie méditerranéennes: Thèse d'Etat.

Tesch J. J. 1946. The thecosomatous Pteropods. I the Atlantic: "Dana Rep." no. 28, 82 p.

Van der Spoel, S., 1972. Pteropoda thecosomata. Conseil International pour l'Exploitation de la mer: Zooplankton Sheet $140-142,12$ p. 